\title{
ANU Allan Martin Lecture 2019-Trump's Republic: An American History
}

\author{
David Farber
}

University of Kansas

Proponents of 'American exceptionalism', from Thomas Jefferson to Dick Cheney, have argued that the United States is an 'empire of liberty', a nation uniquely dedicated 'to the preservation and progress of freedom'. ${ }^{1}$ Donald Trump, for better and most certainly for worse, has stripped away this sort of self-serving optimism about the meaning and history of the United States. Trump speaks to another American vision, a far darker one that has never before been so boldly articulated by an American president. In Trump's republic, order, security, power, hierarchy and 'America First' nationalism rank far higher than America's creedal virtues of liberty, freedom and equality. This vision of America, too, has a history and a powerful constituency within the United States. ${ }^{2}$ Trump did not invent the reactionary nationalism that swept him into the presidency, he inherited it and marketed it anew for an American electorate at the crossroads of its national destiny. Trump and Trumpism are, as the saying goes, as American as cherry pie.

Plenty of others, just in the twentieth century, had cooked up a similar stew of nativism, protectionism and populist right-wing, anti-elitist nationalism. Well before Donald Trump threw his hat into the presidential ring, there had been 1968 presidential aspirant George Wallace, the segregationist governor of Alabama, who had not only championed white supremacy but also a fierce disdain for the 'pointy headed' intellectuals who, he said, were tearing the nation's traditional social fabric apart.

1 The literature on American exceptionalism is broad, if not always deep. For former vice president Dick Cheney's version, see Dick Cheney and Liz Cheney, Exceptional: Why the World Needs a Powerful America (New York: Simon \& Schuster, 2015). The quoted passage appears on page 259. For Jefferson's version, see Richard Immerman, Empire for Liberty (Princeton: Princeton University Press, 2010).

2 I write on this aspect of American political culture in David Farber, The Rise and Fall of Modern American Conservatism (Princeton: Princeton University Press, 2010). 
Six weeks before the presidential election, Wallace led in polls of the American South with the support of 45 per cent of the electorate (he ended up winning five of those states). ${ }^{3}$ And, back when a middle-aged Donald Trump was narrowly focused on two-timing his first wife for the woman who would eventually become his second, though not final, wife, Texas billionaire Ross Perot told Americans that 'the giant sucking sound' they were hearing was the multitude of jobs flowing from the United States to Mexico. ${ }^{4}$ Perot ran as a third party presidential candidate in 1992, gaining nearly 20 per cent of the vote. And, well before Donald Trump was born, even before his father, Fred Trump, fleeced his first New York City tenants, another billionaire right-wing populist, Henry Ford, had sounded out many of the same themes candidate Trump would try out nearly a century later. Ford's zealous supporters hoped he would run for the presidency in 1924 but, in those pre-primary election days, Republican Party leaders put a stop to that notion. ${ }^{5}$ Of course, none of these men won the presidency: Donald Trump did.

In thinking about Trump's republic and its antecedents within the United States, I want to consider three interrelated American histories. First, I will give a brief historical outline of the cultural underpinnings of the modern American conservative movement-a dynamic, fractious political culture that Trump has fully embraced and refashioned for the contemporary political moment. Second, I will more briefly examine a linked, overlapping but not congruent political formation, right-wing populism, that Donald Trump championed most visibly during his 2016 campaign and that he continues to foreground in his presidential rallies, Twitter feed, and in his general contempt for such constitutionally protected institutions as Congress and the free press. Finally-and very much linked to the performance of Trump's right-wing populism-I will ponder the history of humbuggery and spectacle both in American culture and in American politics, and consider how and why in contemporary times Trump has been able to use such venerable tools of democratic and market culture to such powerful effect.

3 The best account of George Wallace's rise to national prominence remains Dan T. Carter, The Politics of Rage: George Wallace, the Origins of the New Conservatism and the Transformation of American Politics (New York: Simon \& Schuster, 1995).

4 Harley Shalken, 'The "Giant Sucking Sound" of NAFTA', Conversation, 12 July 2019, theconversation.com/the-giant-sucking-sound-of-nafta-ross-perot-was-ridiculed-as-alarmist-in-1992but-his-warning-turned-out-to-be-prescient-120258.

5 Steven Watts, The People's Tycoon: Henry Ford and the American Century (New York: Knopf, 2005). 
To understand Trump's republic and how Donald Trump succeeded electorally where others of his kind failed, I think we need to see not only why Trump's political messaging has resonated with tens of millions Americans but also how our current historical moment has enabled Trump's leadership style to be so persuasive, recasting American political culture in directions America's founding fathers wrote about with dread and foreboding. In the United States, President Trump is sometimes perceived as an outlier, an unprecedented figure who has disrupted conventional politics - and he is. But he is also very much a product of American political culture, which makes him a far more significant and powerful actor on the national and world stage.

So, first, a brief history of modern American conservatism, Donald Trump, and Trump's republic. Conservatism, as practised by Donald Trump but also by his major political antecedents in the United States, is a kind of odd job word-a dynamic, flexible political term of art more than a definitive ideological set of principles. Trump, like those before him, has put his own spin on what it means to be a conservative Republican. Still, even the never-read-a-book-by-a-conservative-writer-in-his-life Donald Trump shares in several loosely applicable notions of American conservatism, a broad dispositional cast or set of political beliefs conditioned by decades of political struggle. ${ }^{6}$

Political conservatives in recent decades have tended to embrace, as I have already said, traditional social hierarchies and to scorn those who would overturn them. Broadly, they have also embraced the free market as the best adjudicator of Americans' economic life course while distrusting the benevolent hand of the federal government. Many, though not all, conservatives have trusted faith, faith-based knowledge and family, rather than secular knowledge or experts, as the primary provider of moral truths and practical wisdom. Further, most have scorned a multilateral approach to foreign policy or any sense that the United States is but one nation among many; instead, most conservatives pride themselves on an unyielding and unalloyed love of country and a firm belief in unilateralism in foreign affairs. Not surprisingly, given the everyday meaning of the term conservatism, self-avowed conservatives seek to conserve, they tend to look to the past for guidance- to a time when society and culture 'were as they

6 This overview is derived from Farber, The Rise and Fall. The literature on American conservatism is voluminous. For a more glowing assessment of that history, see Donald T. Critchlow, The Conservative Ascendency (Lawrence: University Press of Kansas, 2011). 
should be'-when they were, one might say, 'great'. Thus, conservatives have tended to fear challenges to the standing order. Conservative leaders have often used such fears to make and mobilise new constituencies who feel themselves threatened by specific social and cultural changes.

In response to liberals' claims that the state needs to discipline the capitalist marketplace, conservatives have overwhelmingly argued that, in fact, it is individuals that need disciplining through the rigours of the free market and the enduring claims of religious faith and traditional family values. Such an assemblage of principles and practices did not emerge all at once nor did —or do—all conservatives embrace every aspect of it. Conservatives have struggled over several generations to create a broad-based movement flexible enough to exercise national political power. The constituent elements of modern American conservatism I have just listed are the result of that political process more than they are the predetermined outcome of a rigorous philosophical exegesis of first principles. Donald Trump, in his own pursuit of political power and public prominence, has pushed against some of these contingent conservative prescriptions-but not much.

Even in those areas of national life where he is often criticised by conservative pundits and so-called 'Never-Trumpers' within the Republican Party for having forsaken core conservative ideals, he could — if he cared, which I am confident he does not-find prior conservative icons who championed his more controversial policy preferences. And-a more substantial pointsome of what Trump has proffered to the American people is very much in a long American conservative popular policy tradition-a popular tradition that perhaps was only temporarily, if powerfully, disrupted by the 50-year-long duration of the elite-managed Cold War.

One of President Trump's most emblematic phrases-which he used to great effect in the 2016 presidential campaign, continues to use in his political rallies, and plays a fundamental role in shaping his approach to international alliances and economic relations-is 'America First'. Trump's use of the phrase in his early presidential campaigning days shocked most historically well-informed listeners (a paltry number it need be said) in the United States. An educated remnant knew that 'America First' was the slogan of organised isolationists who sought to keep the United States from coming to the aid of the British Empire against the Nazi onslaught in the dark days of 1940 and 1941. 
America First's most renowned champion was the aviator-hero Charles Lindbergh, who wrapped his opposition to intervention with a cheerful respect for Adolf Hitler and an undisguised contempt for Jews. In the Fall of 1941, Lindbergh warned Jewish Americans to stop seeking America's entry into the war:

Jewish groups in this country should be opposing it ... for they will be the first to feel its consequences. Tolerance is a virtue that depends upon peace and strength. ${ }^{7}$

Lindbergh was saying that, if Americans were forced to fight, Jews, whose pro-war views he insisted were motivated for 'reasons that were not American', would properly be blamed by the American people for the cataclysm that followed. ${ }^{8}$

Once America did join the war against the forces of fascism and militarism, the term 'America First', mostly disappeared. At war's end and during the advent of the Cold War, internationalists of all stripes-a group that included post-World War II Republican leaders such as Dwight Eisenhower and Richard Nixon-rejected the term, perceiving it to be an ignorant, even immoral shorthand for an ill-conceived approach to America's role in the world. Yet, despite the seeming banishment of 'America First' from conventional political lexicon, within both the Republican and Democratic parties during the post-WWII and Cold War years, some important critical figures-Donald Trump's direct antecedents—carried the 'America First' torch forward.

Among the most prominent was Ohio Senator Robert Taft, known in his time as 'Mr Republican' and a major progenitor of modern American conservatism. Taft hated America's postwar internationalist turn. He despised NATO. Above all, he fought reciprocal trade agreements between the United States and its anti-communist Cold War partners. Taft-like President Trump—was an unabashed supporter of capitalism but he was no follower of libertarian economists and their unalloyed faith in free trade. Taft believed in state support of American capitalists not international capitalism: in other words-American First. ${ }^{9}$

7 Charles Lindbergh, 'Des Moines Speech', 11 September 1941, accessed 9 June 2020, www.charles lindbergh.com/americanfirst/speech.asp.

8 Lindbergh, 'Des Moines Speech'.

9 David Farber, 'America First and International Trade Policy in the Early Cold War', Passport: The Society for Historians of American Foreign Relations Review (September 2018): 39-41. 
Taft was not an outlier in his party. Such strong opposition to free trade and internationalism had been a fundamental tenet of the Republican Party since its origins in the 1850s. However, with the advent of the Cold War, the Republican Party had split over the issue. Dwight D. Eisenhower, a fervent internationalist, proudly championed a new 'modern Republicanism'. ${ }^{10}$ Between 1946 and well into the twenty-first century, this internationalist policy of economic support and openness to free trade, even trade that advantaged other nations, became fundamental to American policy elites' approach to global management. International trade, they believed, helped create a stable international order in which the world's wealthiest and most powerful nation-the US-would reap substantial economic and geopolitical benefits. The Taftian anti-free trade, anti-multilateral America First persuasion was out of vogue in both the Republican Party and the conservative movement throughout most of the last decades of the twentieth century, but it was not forgotten. In 1992, during the first post-Cold War election campaign that followed the implosion of the Soviet Union, Taftian American First conservatism was reincarnated in twin form.

Ross Perot, a billionaire Texan, ran a third party presidential campaign on a single issue. President Bush's attempt to create a North American Free Trade Agreement (NAFTA) with Mexico and Canada, Perot twanged, would be a disaster for American workers. Free trade, he argued, was a problem not a solution for America's post-Cold War economic challenges. In a similar vein, George H. W. Bush's competitor for the 1992 Republican nomination, former Nixon speechwriter and media pundit Pat Buchanan, also condemned the entire logic of Cold War economic internationalism:

We call for a new patriotism, where Americans begin to put the needs of Americans first, for a new nationalism where in every negotiation, be it arms control or trade, the American side seeks advantage and victory for the United States ... America first. ${ }^{11}$

10 William Hitchcock, The Age of Eisenhower (New York: Simon \& Schuster, 2018).

11 'Pat Buchanan Presidential Campaign Announcement', 10 December 1991, C-Span, accessed 9 June 2020, www.c-span.org/video/?23289-1/pat-buchanan-presidential-campaign-announcement. 
Buchanan knew exactly what resonances 'America First' brought forthbesides attacking NAFTA and other free trade policies, he echoed Charles Lindbergh; he blamed the influence of cosmopolitan Jewish Americans for America's turn to a global economic regime. ${ }^{12}$

Pundits dismissed Buchanan as a 'paleoconservative', contrasting his protectionist, anti-internationalist stance to that of 'modern Republicans' such as Bush and some of his closest advisers, who championed an ever greater role for America in the international area. These conservative internationalists had been rebranded as 'neo-conservatives'. In 1992, Bush easily defeated Buchanan. Forty years after Taft had lost his bid for the Republican presidential nomination to Eisenhower, American First conservatism seemed to have again been marginalised. ${ }^{13}$ We know now that it had not been; it was a popular conservative policy position only awaiting a better spokesmen operating in a more welcoming political and economic moment.

A second point on Trump and his place in the conservative political movement: if Donald Trump has revived an older kind of conservatism (a 'paleoconservatism') when it comes to matters of international trade and America's broader role in the world, he is much more in the conservative mainstream in his divisive, nativist and at times vitriolic views on national identity-of who really counts as an American citizen. From the origins of modern American conservatism as an organised political force in the anti-New Deal big business circles, conservative activists have sometimes gingerly and often exuberantly aligned themselves with the most intolerant of Americans. The targets of that intolerance have changed in saliency over time but conservatives' principal claim has remained the same: some people are more deserving of the rewards of American citizenship than are others. Most elite economic conservatives who aligned themselves then and thereafter with such 'deplorables' often did so for a simple reason: welcoming such people into the conservative movement broadened their ranks across class lines and made a winning electoral coalition possible.

12 For an overview of Buchanan's history of anti-Semitic remarks see James Kirchick, 'Pat Buchanan and His Enablers', Columbia Journalism Review, 23 February 2012, archives.cjr.org/campaign_desk/ pat_buchanan_and_his_enablers.php.

13 For Pat Buchanan and the politics of the 1990s, see the detailed account in Steve Kornacki, The Red and the Blue: The 1990s and the Birth of Political Tribalism (New York: HarperCollins, 2018). 
One can smell this unpleasantness permeating American conservatism for a good many decades. The economic libertarian big business leaders who sought to organise a conservative coalition to defeat Franklin Roosevelt in the 1930s aligned themselves, cynically, with white supremacists and anti-Semites. ${ }^{14}$ In the late 1950s, conservative champion and subsequently Republican nominee for the presidency, Senator Barry Goldwater, found new supporters when he toured the South and spoke out against government-mandated civil rights enforcement. In 1964, Goldwater voted against the landmark Civil Rights Act (despite strong Republican Party support for it) and he told his aides that, if he and the conservative movement had any chance of winning the presidency that year or thereafter, they had to 'go hunting where the ducks are', meaning that conservatives had to convince white supremacists in the South-and anywhere else in the United States-that conservatism was opposed to mandating equal citizenship for Black Americans. Goldwater had an ideological apology for his anti-civil rights stance. He opposed most federal action that sought to regulate market actions, but his vocal opposition was, above all, politically motivated: he needed to broaden the base of the conservative movement that he led. ${ }^{15}$

Ronald Reagan, generally remembered in the United States for his sunny 'morning in America' sort of conservatism, nonetheless pursued that same racially exclusionary logic with a vengeance. To open his campaign for the presidency, after winning the Republican nomination, he gave a speech on states' rights before an all-white crowd in Neshoba County, Mississippi. White supremacists, as well as Black Americans, got the unsubtle message; 16 years earlier, Neshoba County had made the nation's newspaper headlines when members of the Ku Klux Klan, supported by local law enforcement, had lynched three civil rights activists. Reagan needed to win the South and he was more than willing to reach out to white supremacist voters to clinch his victory against his opponent, the former governor of Georgia Jimmy Carter, who had swept the South in winning the presidency in $1976 .{ }^{16}$

14 I discuss this odd alliance in David Farber, Sloan Rules (Chicago: University of Chicago Press, 2002), 183-84.

15 Rick Perlstein, Before the Storm, (New York: Hill and Wang, 2001).

16 Farber, The Rise and Fall, 190-91. 
Conservative activists in the 1960s, '70s, '80s and '90s found new constituencies and electoral victories by championing intolerance, attacking each and every new iteration of calls for equal rights-first of African Americans, then of feminist women and then of members of the LBGTQI+ community. As attacks on each group's demands for full equality and inclusion became less accepted by ever more Americans, mainstream conservatives toned down the blatancy of their vitriol, turning instead to so-called 'dog whistle' attacks, even as more extreme conservative groups, especially in the age of social media, kept up their calls for a return to a time when racial exclusion, heteronormativity and patriarchy ruled the nation.

In the early twenty-first century, more and more so-called establishment conservative politicians had walked away from that kind of hateful intolerance. George W. Bush, running in 2000, insisted that he was, on those grounds, a new kind of conservative. Just as 'Modern Republican' Dwight Eisenhower had broken with 'Mr Republican', Robert Taft, in the 1950s, so Bush was making a break with the successful Republican leaders who had preceded him, including his own father. Bush explained that he was a 'compassionate conservative'. Whereas his father had run for the presidency in 1988 by deploying an infamous, racially charged television commercial featuring a recidivist Black rapist to delegitimise his opponent, the younger Bush insisted that he believed in an equitable, inclusive society. ${ }^{17}$

After the 9/11 attacks, President Bush was as good as his word. At a time when anti-Muslim hysteria was exploding in the United States, Bush flanked himself with Muslim Americans and told the American people that 'Islam is peace':

Those who feel like they can intimidate our fellow citizens to take out their anger don't represent the best of America, they represent the worst of humankind, and they should be ashamed of that kind of behavior. ${ }^{18}$

Here was creedal Americanism at its best.

17 'Fact Sheet: Compassionate Conservatism', 30 April 2002, The White House: President George W. Bush, accessed 9 June 2020, georgewbush-whitehouse.archives.gov/news/releases/2002/04/2002 0430.html.

18 “'Islam is Peace”, Says President', 17 September 2001, The White House: President George W. Bush, georgewbush-whitehouse.archives.gov/news/releases/2001/09/20010917-11.html. 
Senator John McCain, when he ran against Barrack Obama in 2008, maintained this inclusionary vision of Republican Party conservatism. Famously, when one of his supporters at a rally fulminated against Obama, asserting that he could not be trusted because he was not really an American, that he was an Arab, McCain cut her off. He took the microphone out of her hands and emotionally, if somewhat problematically, retorted: 'No, ma'am. He's a decent family man [and] citizen that I just happen to have disagreements with on fundamental issues ... He's not [an Arab]. ${ }^{19}$ Leading establishment conservative Republicans had turned towards decency, inclusivity and equal rights for all. In this turn, Donald Trump saw political opportunity.

If leading Republican conservatives would not deploy racial and exclusionary politics, Trump would. He believed that McCain had been too easy on Obama and it had cost him the 2008 election. Trump looked, instead, to the playbook of intolerance that had greatly expanded the conservative Republican base and worked so well electorally for both Ronald Reagan and the first George Bush. Just as Trump had resurrected the America First canon of an earlier conservative movement, so too would he return to its reactionary populist tradition of intolerance and reactionary inequality in his hunt for a new winning electoral coalition. Trump's use of these tropes of intolerance is not new but he embraced them with an unprecedented zeal. And, in his use of them, he found a welcoming populist conservative base of support.

In 2011, Trump introduced himself to millions of conservative Americans as a sympathetic political figure by leading the anti-Obama 'birther movement'. Trump was already a national celebrity, first for his bestselling books that extolled avarice and chicanery in the pursuit of wealth, and then for his blockbuster television show, The Apprentice. But, until then, very few thought of him as a potential political leader, let alone president.

Trump first broadcast his claim that President Obama was lying about his American origins on the FOX network's Laura Ingraham Show. 'He doesn't have a birth certificate', Trump explained:

19 Jonathan Martin and Amie Parnes, 'McCain: Obama Not An Arab, Crowd Boos', Politico, 10 October 2008, accessed 9 June 2020, www.politico.com/story/2008/10/mccain-obama-not-anarab-crowd-boos-014479. 
Or if he does, there's something on that certificate that is very bad for him. Now somebody told me-and I have no idea if this is bad for him or not, but perhaps it would be-that where it says 'religion', it might have 'Muslim'.

Then, on CNN, he escalated his claims: 'if he wasn't born in this country, he shouldn't be president of the United States' ${ }^{20}$ Trump continued in this vein for the next six years. He appeared regularly on conservative cable television and conservative talk radio and tweeted message after message to cast aspersions on the legitimacy of America's first Black president. Obama, Trump repeated over and over again, was not a real American.

Trump saw the anti-Obama birtherism message as a political winner. He mocked 2012 Republican nominee Mitt Romney's refusal to use the issue, tweeting in August 2012: 'Why do the Republicans keep apologising on the so-called 'birther' issue? No more apologies - take the offensive!' At least among the Republican Party base, Trump had a point. Prior to the 2012 election, a majority of them told pollsters that they did not believe that Obama was born in the United States and thus was not a legitimate president; only 28 per cent disagreed with the claim. Trump had found his political voice and, to be blunt, a racist base of support. ${ }^{21}$

When Trump announced his run for the presidency from the lobby of one of his gilded towers, he pivoted off his birtherism claims to an even more harsh rhetoric of intolerance. In a stream of consciousness address-a style to which people around the world would soon grow accustomed-Trump led with the anti-Mexican immigrant claim that would become one of his trademarks:

When Mexico sends its people, they're not sending their best ... They're sending people that have lots of problems, and they're bringing those problems with them. They're bringing drugs. They're bringing crime. They're rapists. ${ }^{22}$

20 An excellent overview of Trump and birtherism is available online, see Charles Sykes, 'A Short History of Trump's Birtherism (And How the GOP Reacted)', 29 November 2017, The Contrarian Conservative, accessed 9 June 2020, www.thecontrarianconservative.com/blog/2017/11/29/a-shorthistory-of-trumps-birtherism-and-how-the-gop-reacted. Sykes is a well-known conservative (he ran a popular talk radio show in Wisconsin for 23 years) who never supported Trump.

21 Trump's Romney tweet and the statistics are quoted in Sykes, 'A Short History'.

22 Michele Ye Hee Lee, 'Donald Trump's False Comments Connecting Immigrants and Criminals', Fact Checker, Washington Post, 8 July 2015, accessed 9 June 2020, www.washingtonpost.com/news/ fact-checker/wp/2015/07/08/donald-trumps-false-comments-connecting-mexican-immigrants-andcrime/?utm_term=.579824be3e2a. 
Soon thereafter, countering President Bush and the United States' explicit constitutional ban on any form of government-mandated religious discrimination, Trump added immigrant Muslims to his list, telling supporters that he would institute 'a complete shutdown of Muslims entering the United States until our country's representatives can figure out what is going on' ${ }^{23}$

In his presidential campaign, conservative stalwart Barry Goldwater had targeted African Americans struggling for full citizenship in hopes of winning over racist whites. Ronald Reagan built on that base and successfully added anti-feminist and anti-gay constituencies. In that grand tradition, in the 2016 presidential race, Trump found new groups to demonise: Mexican immigrants, Muslims and then Central Americans, further expanding his base by ginning up the fears of his supporters. Hillary Clinton would impoliticly tell a campaign audience that half of Trump's supporters belonged in a 'basket of deplorables'. While theatrically taking great umbrage at the accusation, Donald Trump hoped she was right. At a time when a segment of white Christian Americans feared that the demography of the United States was fast changing, leaving them less powerful and privileged than they had before been, Trump fed their anxieties. No 'compassionate conservatism' for Donald Trump-he wished to go back to the whiter, more Christian, more patriarchal times when, he and his supporters would argue, America was great.

Donald Trump's brand of conservatism, pundits have noted, differed from that of more establishment conservatives such as John McCain, Mitt Romney, Jeb Bush, Senate Majority leader Mitch McConnell and the erstwhile House Speaker Paul Ryan, in its explicit populist message. And, in substantive ways, they are right. Trump's rhetoric is decidedly more populist. At his rallies and on his ubiquitous Twitter feed he is fervently anti-elitist, sneeringly anti-intellectual, proudly plainspoken and ostentatiously vulgar. In his policy claims, he often proclaims himself to be a defender of the common folk. Unlike many conservative Republicans, he has repeatedly promised to safeguard major government programs that protect working-class and middle-class Americans, such as the social security system, and to fight big corporations' offshoring

23 Steve Holland and Emily Stephenson, 'Donald Trump Urges Ban on Muslims Entering United States', 7 December 2015, Reuters, accessed 9 June 2020, www.reuters.com/article/usa-election-trump/ donald-trump-urges-ban-on-muslims-entering-united-states-idUSKBN0TQ2QT20151208. 
of industrial jobs and factories. Trump prides himself on being a populist champion of American workers and certainly in the 2016 election that image contributed to his victory.

In the United States, and quite often in almost any democratic nation, such appeals to the common man are par for the course. In the United States, back in the late 1820s, the rough-hewn but wealthy Tennessean slave master Andrew Jackson-Donald Trump's favourite presidentbroke precedent by running for the presidency as the tribune of the common man. He lambasted what he called the 'aristocrats' who had long controlled the White House. His opponent, fittingly enough, was John Quincy Adams, son of America's second president - a kind of early nineteenth-century antecedent to both Hillary Clinton and the Bushes. Jackson promised that, if elected, he would (referencing Hercules's mighty mythic deed) 'sweep the Augean stable'; in other words, he would, in Trumpian terms, 'drain the swamp' of the corrupt and well-born men who had taken over the people's government in Washington DC. ${ }^{24}$ Jackson was the first but by no means the last to run an explicitly populist, anti-elitist campaign. Indeed, in 1840, William Henry Harrison took the man-of-the-people routine to new heights-heights of hypocrisy, that is_-running as the 'log cabin and hard cider' candidate, while decrying his opponent as a wealthy snob. Harrison, of course, was actually quite wealthy and his opponent, incumbent president Martin Van Buren, came from a poor, hardscrabble family. Harrison, need it be said, won. ${ }^{25}$

Trump was thus, in some ways, just one more in a very long list of menmany of whom were wealthy_who ran for the presidency as a populist outsider, claiming they would clean out the corrupt elite insiders who ran the United States. But Trump is not just a run-of-the-mill populist. His populism is of a more distinct, if not typically, US kind. Trump embodies a populist leadership style more common in the other America-Latin America, that is - though certainly the United States has had its share of what might best be called reactionary populist leadership. ${ }^{26}$ Back in the

24 Donald B. Cole, Vindicating Andrew Jackson (Lawrence: University Press of Kansas, 2009); Lynn Hudson Parsons, The Birth of Modern Politics: Andrew Jackson, John Quincy Adams, and the Election of 1828 (New York: Oxford University Press, 2009), doi.org/10.1111/j.1542-734X.2009.00722_17.x. 25 The 1840 presidential race has been called the first 'image campaign'. See Ronald G. Shafer, The Carnival Campaign: How the Rollicking 1840 Campaign of 'Tippecanoe and Tyler Too' Changed Presidential Elections Forever (Chicago: Chicago Review Press, 2016).

26 I borrow here from Omar G. Encarnación, 'American Caudillo: Trump and the LatinAmericanization of U.S. Politics', 12 May 2016, Foreign Affairs, accessed 9 June 2020, www.foreign affairs.com/articles/united-states/2016-05-12/american-caudillo. 
mid-1950s, in response to the populist appeal of the demagogic, antiCommunist Senator Joseph McCarthy, the historian Richard Hofstadter wrote a scathing assessment of American populism. ${ }^{27}$ Much but not all of Hofstadter's historical critique could be applied to Donald Trump.

Focused on the late nineteenth-century rise of the populist movement and its great champion William Jennings Bryan, Hofstadter condemned populists for their provincialism, embrace of anti-Semitic conspiracy mongering and virulent nativism. He mocked their yearning for a return to a golden, imaginary time when, they insisted, their kind-white Christian farmers - were seen as the critical backbone of the nation. Historians since the time of Hofstadter have tended to treat the late nineteenth-century populist movement more sympathetically, but for our purposes his critique is telling. ${ }^{28}$ Populist leaders and their followers have almost always blamed their relative loss of status and perceived economic insecurity on a corrupt elite who have turned the nation away from its proper path, away from the traditions and beliefs- the culturethat had long kept the righteous people safe, secure and stable. Donald Trump certainly fits that bill. But Trump also represents a sort of populist appeal that Hofstadter did not see as characteristic of historic American populist leaders.

The typical American populist spoke in the name of the people, as their servant leader. In what is still one of the most famous speeches given by an avowed American populist, the 'Cross of Gold' speech by William Jennings Bryan, the people not the leader are given primacy of place. Bryan speaks almost only in the plural voice: 'It is for these that we speak ... We are fighting in the defense of our homes, our families, and posterity. ${ }^{29}$ Bryan's voice and his cause are given strength by all those with whom he is allied: 'the commercial interests and the laboring interests and all the toiling masses'. The rich men who seek to exploit those masses, he intones, 'shall not press down upon the brow of labor this crown of thorns. You shall not crucify mankind upon a cross of gold. ${ }^{30}$

27 Richard Hofstadter, The Age of Reform (New York: Knopf, 1955), chapters 1-3.

28 For the current historiographical approach, see Charles Postel, The Populist Vision (New York: Oxford University Press, 2007).

29 William Jennings Bryan, 'Cross of Gold', 9 July 1896, History Matters, accessed 9 June 2020, historymatters.gmu.edu/d/5354/.

30 Bryan, 'Cross of Gold'. 
Trump is no populist servant leader. Trump is populist as caudillo, as the unsullied, incorruptible warrior. 'I alone can fix it ... I am your voice', he famously decreed. ${ }^{31}$ Trump's critics heard in such grandiose claims a kind of demagoguery too often associated with authoritarian rulers and not with traditional democratic practices. His devoted followers heard something else. Trump's reactionary populism-like that of many of his favourite leaders around the world-depends on his supporters' willingness to dismiss civility, propriety and even legal boundaries as tools of the cosseted elite and their pet minorities that impede the need-the people's demand-for decisive action to protect their interests against those they deem undeserving and the corrupt.

Trump insisted in his presidential inaugural address that America was at a precipice, overrun with venality, corruption and murderous violence. 'This American carnage', he intoned, 'stops right here and stops right now' ${ }^{32}$ The fact that violent crime in the United States was just a fraction of what it had been 20 years earlier, that America's big cities were, overwhelmingly, the safest they had been in generations, did not matter. Trump promised he would use whatever means were necessary to pursue his objectives and safeguard his supporters. Two years after his inauguration, frustrated by Congress's refusal to do his bidding on immigration policy, President Trump declared a national emergency and rejected America's constitutional precept that only the House of Representatives could appropriate federal money. More recently, he has decreed that he and his administration can simply reject Congress's constitutionally guaranteed right to exercise oversight on the presidency. Trump's supporters and conservative members of Congress have, in all instances, cheered him on. ${ }^{33}$

31 For Trump's acceptance speech at the Republican National Convention and its critics, see Yoni Applebaum, "I Alone Can Fix it”, Breaking with Two Centuries of Political Tradition', The Atlantic, 21 July 2016, accessed 9 June 2020, www.theatlantic.com/politics/archive/2016/07/trump-rnc-speechalone-fix-it/492557/.

32 Donald Trump, 'The Inaugural Address', 20 January 2017, accessed 9 June 2020, www.white house.gov/briefings-statements/the-inaugural-address/.

33 In an extraordinary act of institutional self-abnegation, during the early 2020 impeachment trial, Senate Republicans, in near unanimity, acceded to President Trump's claims that he did not have to cooperate in any way with Congressional investigations if he did not want to. For a pithy overview of Congress's investigatory powers see 'Investigation and Oversight', United States House of Representatives, accessed 9 June 2020, history.house.gov/Institution/Origins-Development/Investigations-Oversight/. 
Trump understands how a sizeable segment of the American people actually feel about their constitutional republic with its checks and balances and its elegant Bill of Rights. At times of trouble, a majority of Americans have dismissed such pieties. In 1970, after years of political polarisation marked by mass demonstrations, unruly protests and violent upheavals, Americans told pollsters that they had had enough. They wanted order, regardless of what the constitution said: 76 per cent of those polled said the first amendment right to assemble and dissent from government policies should be rolled back. A clear majority blamed, somehow, the mass media for egging on protesters and told the same pollsters that they did not support the freedom of the press, either. ${ }^{34}$ Back in 1933, as the Great Depression raged in the United States, Franklin Roosevelt told the American people that, if Congress did not accede to the need for 'bold action', he would be forced to act without them. Few doubted that the American people would have supported him. The constitutional republic and the republic of fear have long been in tension in the United States.

In Trump's republic, every day is a fearful emergency, and the need for bold leadership, unhindered and unimpeded by America's often slowmoving constitutional machinery of governance, is, therefore, a necessity. America's intellectual elite, whether liberal or conservative, has voiced alarm at the fragility of America's constitutional order under President Trump. President Trump, every day, is not unlike President Richard Nixon in his last days. Nixon famously defended his Watergate improprieties by declaring that: 'Well, when the president does it [whatever 'it' is], that means that it is not illegal. ${ }^{35}$ Trump, as well as his attorney-general, would seem to agree. ${ }^{36}$

America's founding fathers understood the fragility of the constitutional order they had created; they worried about the demos and its susceptibility to demagogues. In particular, they had debated the power and place of a democratically elected president upon whose shoulders so much responsibility was placed. Still, it is unlikely that they could have predicted a Donald Trump. Alexander Hamilton, who argued most

34 'Most in Poll Favor Limiting Freedoms', New York Times, 16 April 1970, 37.

35 Nixon made the statement in a televised interview with David Frost, 19 May 1977.

36 For a brief scholarly overview of Attorney-General William Barr's approach to executive power, see Bradley D. Hays, 'What William Barr Misses about Presidential Accountability', Made by History, Washington Post, 5 May 2019, accessed 9 June 2020, www.washingtonpost.com/outlook/2019/05/05/ what-william-barr-misses-about-presidential-accountability/?utm_term=.44ea4deac79b. 
strongly for a powerful executive, countered the fears of his colleagues who, influenced by classic texts, worried that a populist demagogue could win the presidency and therefore corrupt or even destroy the American republic. 'Talents for low intrigue, and the little arts of popularity', he conceded, 'may alone suffice to elevate a man to the first honors in a single State'. He insisted, however, that the multiple constituencies, conflicting interests, free press and sheer intelligence of the national electorate would protect the United States from a demagogue:

It will require other talents, and a different kind of merit to establish him [a presidential candidate] in the esteem and confidence of the whole Union, or of so considerable a portion of it as would be necessary to make him a successful candidate for the distinguished office of President of the United States. ${ }^{37}$

Alexander Hamilton died well before Andrew Jackson ran his populistorientated campaign.

A strong case can be made that Hamilton was wrong and that 'talents for low intrigue and the little arts of popularity' have repeatedly seduced the national American electorate. Trump is by no means the first presidential candidate or president to deploy such arts. Indeed, the American electorate has long enjoyed sussing out the veracity of their politicians' various and varying rhetorical claims. At the same time, the electorate has long judged political rhetoric not simply—or at all—on its adherence to empirical reality but to its value as entertainment, as well as to its ability to stir the passions and bond its listeners to some kind of community, be it partisan or otherwise.

In nineteenth-century America, when cultural authority in the chaotic United States was diffuse and uncertain and government oversight over the flow of marketplace information and claims was nearly non-existent, Americans regularly struggled in the public arena to tell lie from truth. Confidence men, practitioners of fraud and swindle, were a regular staple in both real life and in the writings of America's leading authors, men such as Herman Melville and Mark Twain. ${ }^{38}$ P. T. Barnum became America's leading showman by playfully challenging his mass audience to detect the difference between his genuine spectacles (such as the 3-foot-tall General

37 Alexander Hamilton, 'The Federalist Papers: No. 68', 14 March 1788, Yale Law School, accessed 9 June 2020, avalon.law.yale.edu/18th_century/fed68.asp.

38 Karen Halttunen, Confidence Men and Painted Women (New Haven: Yale University Press, 1986). 
Tom Thumb) and his artful humbuggery (most famously, the so-called Fiji mermaid). His bestselling account of his endeavours, well before Trump but perfectly Trumpian, was The Art of Money Getting. He also wrote another bestseller, Humbugs of the World, in which he explained that, having fooled so many people for so long, only he could teach people how to avoid being fooled again. Sound familiar? Barnum, like Trump, often let his audience in on the joke. And people in the know enjoyed explaining the operational aesthetic behind Barnum's humbugs. ${ }^{39}$

In the twenty-first century, the breakdown in cultural authority-in the United States and in many other nations that enjoy access to 24-hour news stations and an uncensored if also unhinged internet and social media universe- has again created an unadulterated world of humbuggery and confidence men. The cultural and institutional guardrails that had deterred, if never stopped, such rampant humbuggery have lost their power. Technical change drives some of that loss. News organisations that took pride in professional standards of journalism have lost their audiences as they compete against more populist, crowd-sourced, click-based, spectacle-driven forms of infotainment, which is then distributed globally by anyone, including malevolent, wilfully destructive government actors. Then, too, at least in the United States, the deceit and lies of government officials, going back to the days of the Vietnam War and forward to the Bush administration's false claims of weapons of mass destruction in Iraq, have undercut the ability of authorities of all kinds to be trusted by a rightfully sceptical, even cynical, populace.

Donald Trump, who had long made his living humbugging investors, bankers, customers, contractors and anyone else within his wobbly orbit, saw in this chaotic cultural realm an opportunity to reach for the political stars. Not unlike P. T. Barnum and other spectacular flim-flam men then and now, he had an advantage over most, though not all, people who sought public office- he was without shame or conscience. Trump was the demagogic figure of 'low arts' that the founding fathers feared. He was also the demotic figure that the authors of America's constitution believed they had fenced in: Congress, the Supreme Court and the Bill of Rights were all aimed at checking and balancing the power of an unhinged demagogue. One bad actor, even if president, America's founding fathers believed, could not destroy the republic. Of course that malevolent

39 Neil Harris, Humbug: The Art of P. T. Barnum (Chicago: University of Chicago Press, 1981). 
actor could only be checked if a sufficient number of empowered figures acted with courage and integrity. As the 2020 Senate impeachment trial demonstrated, in the era of Trump's republic those checks and those figures of courage and integrity within the national government have been fewer, I think, than the founding generation would have believed possible.

Alexander Hamilton wrote of the dangers of 'a temper fond of despotic power and hostile to the principles of liberty'. In his defence of the constitution that had yet to be ratified, he warned readers to be wary of those who lurk behind the 'specious mask of zeal for the rights of the people' and who spew a 'spirit of narrow and illiberal trust', for those are the 'men who have overturned the liberties of republics, the greatest number begun their career by paying obsequious court to the people; commencing demagogues, and ending tyrants'..$^{40}$ Donald Trump appears to lack the discipline and capacity, if not the will, to cast a republic in his own image, a republic of fear in which liberty, equality and freedom are subservient to the needs of order, security and traditional social hierarchies. Trump's republic of fear, so far, is more spectacle than tyrannical reality. Still, the founding fathers of America's constitutional republic never doubted the fragility of their undertaking. The most witty and prescient of them, Benjamin Franklin, when exiting the Constitutional Convention in Philadelphia in 1787, was asked by an anxious group of citizens what sort of government he and his compatriots had devised. Franklin replied: 'A republic, if you can keep it.' ${ }^{41}$ Well, we shall see if people around the world devoted to republican forms of democracy can keep them in the daunting years ahead.

40 Alexander Hamilton, 'The Federalist Papers: No. 1.', n.d., Yale Law School, accessed 9 June 2020, avalon.law.yale.edu/18th_century/fed01.asp.

41 The famous remark and its historical context is explained by Richard Beeman, 'Perspectives on the Constitution: A Republic If You Can Keep It', National Constitution Center, accessed 9 June 2020, constitutioncenter.org/learn/educational-resources/historical-documents/perspectives-on-theconstitution-a-republic-if-you-can-keep-it. 
This text is taken from ANU Historical Journal II: Number 2, published 2020 by ANU Press, The Australian National University, Canberra, Australia.

doi.org/10.22459/ANUHJII.2020.11 